\title{
Definition of Patent Rights and Examples of Case Studies in iPhone 7 Products
}

\author{
Monika Rizkiana \\ 165100061 \\ Fakultas Komputer, 44757214 \\ Monicarizkiana.student@umitra.ac.id
}

\begin{abstract}
Patent rights is a special right based on the law given to the inventor (uitvinder) or according to the law of the party entitled to obtain it at the request submitted. This patent is exclusive because only inventors produce inventions that can be granted rights, but these inventors can carry out their own inventions or give approval to other parties to implement them, for example through a license.

The invention is an inventor idea that is poured into a specific problem solving activity in the field of technology can be a product or process or a product or process improvement and development.

What inventions can be patented?

The invention can be patented if the invention:

1. If at the time of filing the application the Patent of the invention is not the same as the technology disclosed previously;

2. Contains inventive steps. If the invention is an unpredictable thing for someone who has certain expertise in the field of engineering;

3. Can be applied in industry. If the invention can be produced or can be used in various types of industries.
\end{abstract}

Keywords: Patent Rights and Invention Study 


\section{A. INTRODUCTION}

\section{1st Material DEFINITION OF PATENT RIGHTS}

Patent rights are a special right based on the law given to the inventor or according to the law the party entitled to obtain it at the request submitted to the authorities, for new findings in the field of technology, improvements to existing findings, new ways of working or find a new improvement in the way of working, for a certain period of time that can be applied in the industrial field.

This patent is exclusive because only inventors produce inventions that can be granted rights, but these inventors can carry out their own inventions or give approval to other parties to implement them, for example through a license.

The invention is an inventor idea that is poured into a specific problem solving activity in the field of technology can be a product or process or a product or process improvement and development.

What inventions can be patented? The invention can be patented if the invention:

1. If at the time of filing the application the Patent of the invention is not the same as the technology disclosed previously; 2. Contains inventive steps. If the invention is an unpredictable thing for someone who has certain expertise in the field of engineering;
3. Can be applied in industry. If the invention can be produced or can be used in various types of industries.

\section{How long does the Patent apply?} 1. A patent is granted for a period of 20 years from the date of receipt of a patent application. 2. A simple patent is given for a period of 10 years from the date of receipt of a simple patent application.

How do you apply for a patent? 1. Submit an application to the office of the Directorate General of Intellectual Property (DJKI) in writing in Indonesian by filling in the application form provided and typed in duplicate 2. The applicant must attach: a. special power of attorney, if the application is submitted through a $\mathrm{KI}$ consultant registered as a proxy; b. letter of transfer of rights, if the application is submitted by another party that is not inventor; c. the description of the Patent application is made in duplicate and includes:

- the title of the invention, made in capital letters and not underlined;

- the field of invention engineering, contains generally where the invention is included in the field of engineering by expressing its specificity; - background of the invention, prior technology must be stated and relevant to the invention; - summary of the invention, 
containing technical features of the subject matter of the invention disclosed in the claim;

- a brief description of the image (if a picture is included), contains a brief description of the image;

- a complete description of the invention, which is a complete disclosure of inventions, there must be nothing left behind or not disclosed; - claims (made on separate pages), contain the subject matter of the invention and may not contain images or graphics but can contain tables of mathematical formulas or chemical reactions;

- abstract (made on a separate page), containing a summary of the full description of the invention and no more than 200 words.

i. translation of the description of the invention in English, if the invention is originally in a foreign language other than English;

ii. proof of payment for Patent application fees;

3.Writing descriptions, claims, abstracts and images as referred to in item 2 letters $\mathrm{c}$ and $\mathrm{d}$ are determined as follows:

4. each sheet of paper is only one of its faces which may be used for writing and drawing; 5. descriptions, claims and abstracts are typed in HVS paper or similar and separate, A4 size, minimum weight 80 grams with the following limits: o upper limit: $2 \mathrm{~cm}$ o lower limit: $2 \mathrm{~cm}$ o left border: $2.5 \quad \mathrm{~cm}$ o right border: $2 \mathrm{~cm}$ 6. The A4 paper must be white, flat, not glossy and its use is done by placing the short side at the top and bottom (unless used for pictures); 7. each description sheet, claim and image are numbered in Arabic numerals in the upper middle part and not in the limit as referred to in item 3 letter b (1); 8. in each of the five lines typing the description and claims, must be given a line number and each new page is the beginning (beginning) of the number and placed to the left of the description or claim and not to the limit as referred to in item 3 letter b (3); 9. typing must be done using black ink (toner), with spacing 1.5 and upright letters with a minimum letter height of 0.21

$\mathrm{cm}$; 10. signs with lines, chemical formulas, and certain signs can be written by hand;

The image must use black Chinese ink on A4-size white drawing paper with a minimum weight of 100 grams that is not glossy with the following limits:

$\begin{array}{llccc}\text { o } & \text { upper } & \text { limit: } & 2.5 & \mathrm{~cm} \\ \text { o } & \text { lower } & \text { limit: } & 1 & \mathrm{~cm} \\ \text { o } & \text { left } & \text { border: } & 2.5 & \mathrm{~cm} \\ \text { o } & \text { right } & \text { border: } & 1.5 & \mathrm{~cm}\end{array}$


all submitted Patent documents must be in full sheets of paper, may not be torn, folded, damaged or affixed images;

each term used in descriptions, claims, abstracts and images must be consistent with each other

The second material: Examples of Case Study of IPR (Intellectual Property Rights) in iPhone Series iPhone 7 Products

Patents:

The patent rights of this company are owned by Steve Jobs as the founder and first CEO of the Apple company

Brand:

The trademark of this iPhone company is Apple or the bitten Apple logo.

\section{- $\quad$ Trade}

Secrets:

1. Guaranteed Older OS Update 2. The Best Application Released Early on iOS 3. Better iOS Performance 4. Safer Operating System 5. Made from Premium, Simple and Elegant

Design

5. Best Camera Quality Higher Selling Price 6. The Risk of Being Affected by "Malware"

7. Without Cellular Operator Application

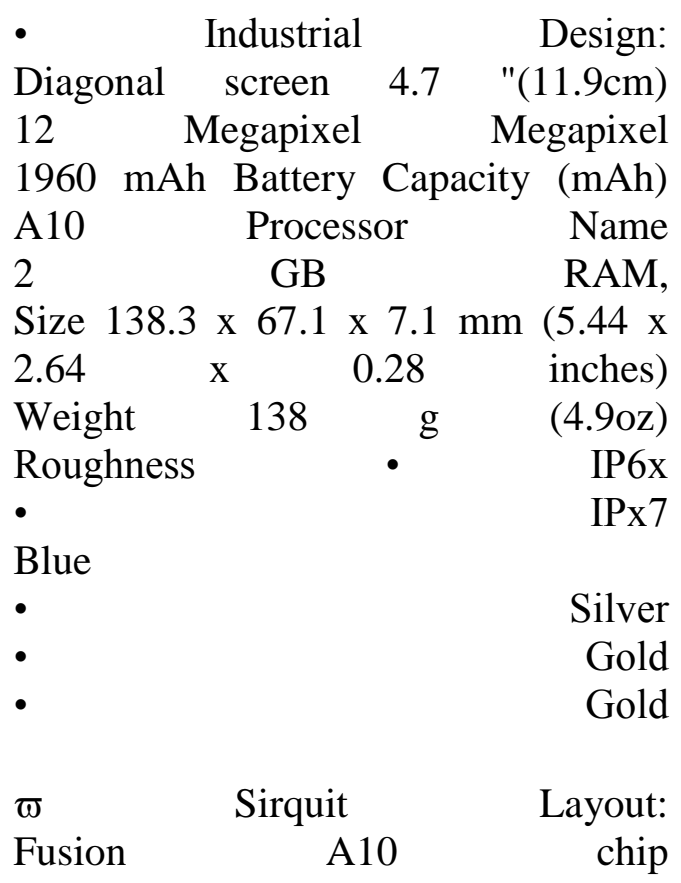

\section{B.}

\section{CONCLUSION}

The conclusion of this material is that every product created has a Patent Right that is given to the inventor (uitvinder) or according to the law the party has the right to obtain it at the request submitted to the authorities, for new findings in the field of technology, improvements to existing findings, ways new work or find a new improvement in the way of working, for a certain period of time that can be applied in the industrial field. 
Indonesia. Retrieved From Osf.Io/Pbrn9.

\section{C.ACKNOWLEDGEMENT}

University Of Indonesia

University Of Mitra Indonesia

Telkom University

University Of Mellbourne

Saitama University

\section{D.REFERENCE (Based ISO 690 )}

A. S. Putra And O. M. Febriani, "Knowledge Management Online Application In Pdam Lampung Province," In Prosiding International Conference On Information Technology And Business (Icitb), 2018, Pp. 181-187.

[2] A. S. Putra, O. M. Febriani, And B. Bachry, "Implementasi Genetic Fuzzy System Untuk Mengidentifikasi Hasil Curian Kendaraan Bermotor Di Polda Lampung," J. Sist. Inf. Dan Manaj. Basis Data, Vol. 1, No. 1, Pp. 21-30, 2018.

[3] O. M. Febriani And A. S. Putra, "Sistem Informasi Monitoring Inventori Barang Pada Balai Riset Standardisasi Industri Bandar Lampung," J. Inform., Vol. 13, No. 1, Pp. 90-98, 2014.

[4] Putra, Arie Setya. "2018 Artikel Struktur Data, Audit Dan Jaringan Komputer." (2018).

[5] Putra, A. S. (2018, July 17). Paperplain Fundamental Create Application With Borland Delphi 7.0 University Of Mitra

\section{E. REFERENCE (Based APA)}

Putra, A. S., Aryanti, D. R., \& Hartati, I. (2018, November). Metode SAW (Simple Additive Weighting) sebagai Sistem Pendukung Keputusan Guru Berprestasi (Studi Kasus: SMK Global Surya). In Prosiding Seminar Nasional Darmajaya (Vol. 1, No. 1, pp. 85-97).

Sari, D. P., Febriani, O. M., \& Putra, A. S. (2018, November). Perancangan Sistem Informasi SDM Berprestasi pada SD Global Surya. In Prosiding Seminar Nasional Darmajaya (Vol. 1, No. 1, pp. 289-294).

Putra, A. S. (2018). Paperplain: Execution Fundamental Create Application With Borland Delphi 7.0 University Of Mitra Indonesia.

Putra, A. S., Sukri, H., \& Zuhri, K. Sistem Monitoring Realtime Jaringan Irigasi Desa (JIDES) Dengan Konsep Jaringan Sensor Nirkabel. IJEIS (Indonesian Journal of Electronics and Instrumentation Systems), 8(2), 221232.

Darmawan, A., Yuliawati, D., Marcella, O., \& Firmandala, R. (2016). Sistem Absensi dan Pelaporan Berbasis Fingerprint dan SMS Gateway. EXPLORE, 7(1).

Febriani, O. M., Wahyuni, T., \& Yusuf, S. (2017). DESIGN OF WEBSITE-BASED INFORMATION SYSTEM FOR EDOCUMENT ADMINISTRASI IN THE 
COMMUNITY SERVICE UNIT (A Case Study at Rajabasa District). INTERNATIONAL JOURNAL OF COMPUTERS \& TECHNOLOGY, 16(7), 7010-7020.

Febriani, O. M., \& Wahyuni, T. (2017, October). PERANCANGAN SISTEM E-DOCUMENT ADMINISTRASI LOGBOOK PENELITIAN PADA UNIT LAYANAN DI BANDAR LAMPUNG. In Prosiding Seminar Nasional Darmajaya (Vol. 1, No. 1, pp. 187-194).

Febriani, O. M., \& Permadi, A. B. (2017). Implementasi Sistem Aplikasi Data Bimbingan dan Pelanggaran Siswa pada Sekolah Menengah Atas di Lampung Tengah dengan Metode Analisis dan Desain Sistem Terdistribusi (SSAD). EXPERT, 7(1).

Febriani, O. M., \& Ambarwati, L. (2015). PERANCANGAN APLIKASI PENGOLAHAN DATA PENJUALAN UKM KELANTING KHAS TELO DESA SIDOHARJO KECAMATAN JATI AGUNG KABUPATEN LAMPUNG SELATAN. Jurnal Teknologi Informasi dan Bisnis Pengabdian Masyarakat Darmajaya, 1(1), 77-95.

Febriani, O. M. (2015). Rancang Bangun Aplikasi Ecommercemenggunakan Freewebstore pada UKM Kelanting di Desa Sidoharjo Lampung Selatan. Prosiding Sembistek 2014, 1(02), 446-458. 